\title{
Toxic elements and heavy metals concentrations in playground of elementary schools of Brandon, Manitoba, Canada
}

\author{
Karimzadeh-Somarin Kian ${ }^{1}$, Somarin Alireza ${ }^{2}$
}

\begin{abstract}
Somarin KK, Somarin A. Toxic elements and heavy metals concentrations in playground of elementary schools of Brandon, Manitoba, Canada. J Environ Geol 2017;2(1): 1-10.

Chemical safety of school playgrounds is very important for the health and well-being of students and it is expected that level of heavy metals [including toxic elements] be below acceptable [non-toxic] levels. The risk from accidental consumption of potentially toxic elements in playground soils is of concern to children's health. Concentration of heavy metals is a very important factor in assigning type of land use. For example, Canadian Council of Ministers of the Environment [CCME] has published soil quality guidelines to help protect environmental and human health. These guidelines identify 4 types of land use in Canada: agricultural, residential/parkland, commercial, and industrial. Different concentrations of heavy metals are suggested for each land use.
\end{abstract}

A total of 73 samples were collected from playgrounds of 16 elementary schools in Brandon, Canada and analysed for major and light elements [Fe, $\mathrm{Ti}, \mathrm{Ca}, \mathrm{K}, \mathrm{Al}, \mathrm{P}, \mathrm{Si}, \mathrm{Cl}, \mathrm{S}, \mathrm{Mg}$ ] as well as trace and heavy metals [As, Ba, Cd, $\mathrm{Cr}, \mathrm{Cu}, \mathrm{Pb}, \mathrm{Mn}, \mathrm{Ni}, \mathrm{Se}, \mathrm{U}, \mathrm{V}, \mathrm{Zn}$. The elemental relationships in these samples show that the data sets were predominantly influenced by natural geologic element dispersion and accumulation processes. Anthropogenic sources generally enrich individual [or small number of] elements and, as a result, distributions are disturbed and skewed towards higher values in natural systems. Lower values are commonly free from anthropogenic influences. This research shows that $\mathrm{As}, \mathrm{Ba}$ and $\mathrm{Cu}$ are the only heavy metals in playgrounds of some schools in Brandon that are higher than, or close to, the values suggested by the Canadian soil quality guidelines.

Key Words: Toxic elements, Heavy metals, School playgrounds, Environmental safety, Soil geochemistry
It is expected that neighborhood and school playgrounds to be safe and clean environments for children to play in. Every day, thousands of school students play on playgrounds; they touch soil and even sometimes eat snack or food after touching soil. The question is that how safe is the soil; are there high levels of toxic elements in the soil, or concentrations of the toxic elements are below acceptable threshold?

Intentional or unintentional consumption of potentially toxic elements in playground soils can be a great risk to children's health. This topic has been a popular research topic in communities worldwide and similar case studies have been carried out in many playgrounds. For example, toxic levels of $\mathrm{Pb}$, $\mathrm{Ni}$ and As were detected in children's playground in Townsville, Australia (1). In another case study, the concentration of $\mathrm{As}$ and $\mathrm{Pb}$ in soils collected from 12 schools in NE England was compared with Soil Guideline Values from seven countries as well as reported literature concentrations for playgrounds and recreational parks. This research demonstrated that minimal risk arises from the investigated playgrounds provided that good personal hygiene is adhered (2). Soil pollution has become an important environmental issue in China owing to rapid urbanization and industrialization, and increasing reliance on agrochemicals in the last several decades $(3,4)$.

Manta et al. (5) reported an average of 202, 138, 63, and $0.63 \mathrm{ppm}$ for $\mathrm{Pb}$, $\mathrm{Zn}, \mathrm{Cu}$ and $\mathrm{Hg}$, respectively, in green areas and parks in the city of Palermo, Italy. Lavado et al. (6) studied As, B, Ba, Ca, Co, Cr, Cu, Pb, Mn, Hg, Mo, $\mathrm{Ni}, \mathrm{Ag}, \mathrm{Se}$, and $\mathrm{Zn}$ concentrations in topsoil and soil profiles at Pampas, Argentina, and reported that all of the values were within the normal range for uncontaminated soils.

Madrid et al. (7) compared concentration of $\mathrm{Cu}, \mathrm{Cr}, \mathrm{Ni}, \mathrm{Pb}$, and $\mathrm{Zn}$ in urban parks in six European cities with a different climate and industrial history and found out that $\mathrm{Cu}, \mathrm{Zn}$, and $\mathrm{Pb}$ contamination tends to occur together at the same site, while the same was not true with $\mathrm{Ni}$ and $\mathrm{Cr}$ contamination. Clark et al. (8) studied backyard gardens in Roxbury and Dorchester, USA, and reported that $\mathrm{Pb}$ concentrations in these gardens range from 80 to 3680 $\mathrm{ppm}$ with the mean value of $950 \mathrm{ppm}$.

Zheng et al. (9) studied As, $\mathrm{Cd}, \mathrm{Cr}, \mathrm{Cu}, \mathrm{Ni}, \mathrm{Pb}$, and $\mathrm{Zn}$ concentration in topsoil of Beijing, China, and found out that the center of the city has the highest concentration of these metals. They suggested that vehicle exhaust and smelters are the main anthropogenic sources of heavy metal contamination in Beijing.
Szynkowska et al. (10) studied impact of industrial activities and traffic emissions on metal $[\mathrm{Cd}, \mathrm{Cr}, \mathrm{Cu}, \mathrm{Ni}, \mathrm{Pb}$, and $\mathrm{Hg}]$ concentrations in soil samples and the waste product phosphor-gypsum in Lódz and Gdansk, Poland, and compared the results with soil samples taken from potentially uncontaminated sites [Lagiewniki Forest, Central Poland]. They proposed that the source of contaminations is related to the anthropogenic activities as concentrations of the heavy metals increase by approaching the pollution source.

Wei et al. (11) investigated heavy metal concentrations in urban soils, urban road dusts and agricultural soils in China and found out that almost all heavy metal concentrations are higher in urban centers than in the agricultural soils. They also reported that the concentrations of heavy metals vary significantly among the cities and concluded that the contamination of $\mathrm{Cr}, \mathrm{Ni}, \mathrm{Cu}, \mathrm{Pb}, \mathrm{Zn}$, and $\mathrm{Cd}$ is widespread in urban soils in China.

Heidary-Monfared (12) studied $\mathrm{Pb}, \mathrm{As}, \mathrm{Cu}$, and $\mathrm{Zn}$ concentrations in samples from gardens in Halifax Regional Municipality, Canada, using partial digestion analytical method. Soil heavy metal concentrations were compared to the CCME soil quality guidelines for agricultural lands. It was found out that more than one third of samples had higher concentration of $\mathrm{Pb}$ than the CCME guideline. Arsenic contamination was widespread and half of the samples had higher As than the CCME guideline. He concluded that $\mathrm{Pb}$ and As contamination is related to the bed rock.

Jien et al. (13) studied soil profiles from urban parks in Taiwan in order to evaluate the contamination and sources of potentially toxic elements $[\mathrm{Cd}$, $\mathrm{Cr}, \mathrm{Cu}, \mathrm{Ni}, \mathrm{Pb}, \mathrm{Zn}, \mathrm{As}, \mathrm{Hg}$. They reported that $\mathrm{Pb}-\mathrm{Zn}$ and $\mathrm{Ni}-\mathrm{As}$ are from different sources. Also they suggested that $\mathrm{Cu}$ [mean of $91.1 \mathrm{ppm}]$ and $\mathrm{Zn}$ [mean of $126 \mathrm{ppm}$ ] in urbane surface soils of Kaohsiung city are related to industrial activity; $\mathrm{Pb}$ [mean of $56.8 \mathrm{ppm}$ ] in urbane surface soils of Taipei city is related to high traffic; $\mathrm{Ni}$ [mean of $12.8 \mathrm{ppm}$ ] and As [mean of 28.7 $\mathrm{ppm}$ ] in urbane surface soils of Yilan city are below background levels in Taiwan and are related to the parent bedrock [slate and argillite].

Quarshie et al. (14) measured concentrations of the toxic elements As, Cd, $\mathrm{Cr}, \mathrm{Hg}$ and $\mathrm{V}$ in soil and tailings samples from the Bibiani mining area, Ghana. The concentrations of the elements measured in the soil were in the following ranges: As 0.46-996 ppm, Cd 0.69-4.15 ppm, $\mathrm{Hg} 0.01-0.06$

${ }^{1}$ Faculty of Science, Department of Biology, Brandon University, Brandon, MB, Canada; ${ }^{2}$ Faculty of Science, Department of Geology, Faculty of Science, Brandon University, Brandon, MB, Canada

Correspondence: Karimzadeh-Somarin Kian, Faculty of Science, Department of Biology, Brandon University, Brandon, MB, Canada. Telephone (204) 727-9686, e-mail kiansomarin14@gmail.com

Received: November 23, 2017, Accepted: January 10, 2018, Published: January 17, 2018

OPEN $\bigcirc$ ACCESS
This open-access article is distributed under the terms of the Creative Commons Attribution Non-Commercial License (CC BY-NC) (http:// creativecommons.org/licenses/by-nc/4.0/), which permits reuse, distribution and reproduction of the article, provided that the original work is properly cited and the reuse is restricted to noncommercial purposes. For commercial reuse, contact reprints@pulsus.com 
ppm, and V 60-204 ppm. In the tailings, the concentrations of the elements showed different ranges: As [2.70-3.50]×103 ppm, Cd 1.35-3.36 ppm, Cr 19. $87 \mathrm{ppm}, \mathrm{Hg}$ 0.01-0.02 ppm, and V 48-93 ppm. They concluded that tailings dam and mining activities might be the source of As pollution in the area. Concentration of $\mathrm{V}$ was high in both the soil and tailings samples however the levels of $\mathrm{V}$ in the soil were higher than those in the tailings. The levels of $\mathrm{Cd}$ and $\mathrm{Hg}$ in both soil and tailings samples were relatively low and, therefore, did not give any indication of contribution from mining activities.

Cai L et al. (4) studied $\mathrm{Cu}, \mathrm{Zn}, \mathrm{Ni}, \mathrm{Cr}, \mathrm{Pb}, \mathrm{Cd}, \mathrm{As}$ and $\mathrm{Hg}$ concentrations in agricultural soil samples collected from Huizhou, China, and found out that, compared to the soil background contents in Guangdong Province, the mean concentrations of $\mathrm{Hg}, \mathrm{Cd}, \mathrm{Zn}, \mathrm{Pb}$ and $\mathrm{As}$ in soil of Huizhou are higher, especially $\mathrm{Hg}$ and $\mathrm{Cd}$, which were 2.82 and 1.79 times the background values, respectively. They concluded that $\mathrm{Cr}, \mathrm{Ni}, \mathrm{Cu}$, and partially $\mathrm{Zn}$ and $\mathrm{Pb}$ originated mainly from a natural source; $\mathrm{Cd}$, As, and partially $\mathrm{Zn}$ mainly from agricultural practices; $\mathrm{Hg}$, and partially $\mathrm{Pb}$ from industry and traffic sources.

Roca et al. (15) studied variability in the natural background levels of seven heavy metals $[\mathrm{Cd}, \mathrm{Cr}, \mathrm{Cu}, \mathrm{Mn}, \mathrm{Ni}, \mathrm{Pb}$ and $\mathrm{Zn}]$ in soil profiles from the agricultural area of Fray Mamerto Esquiú, Argentina, and reported that $\mathrm{Cd}$ shows slight natural enrichment anomaly. They found out that $\mathrm{Cu}, \mathrm{Fe}$, $\mathrm{Mn}$ and $\mathrm{Zn}$ were enriched in the top horizon due to the high percentage of organic matter.

Knowing the concentrations of trace elements in soils is essential to maintaining environmental quality particularly in assigning type of land use in particular areas. Various environmental agencies, including the Canadian Council of Ministers of the Environment [CCME], have published soil quality guidelines. The Canadian soil quality guidelines identify 4 types of land use (16) (i) agricultural, (ii) residential/parkland, (iii) commercial, and (iv) industrial. Generic guidelines have been developed to protect human and key ecological receptors that have normal activities on any of these four land use categories. Sensitivity to contamination is high in agricultural and residential/parkland land uses due to ecological or human health components in these land use categories. Furthermore, urban gardening [as community or school gardens] has gained momentum in many cities in the last a few years. However, studies have shown that urban soils can have high concentration of certain trace elements [i.e., heavy metals]. These elements can enter the human body through inhalation or ingestion of dust/soil and, to a lesser extent, through the consumption of produce grown in contaminated soil (12), as plant tissues can bio accumulate some heavy metals (17).

The soil of Brandon area, Canada, is generally thought to be uncontaminated. Nevertheless, the urbanization of agricultural soils in this area could potentially distort natural metal distribution. This is a very important issue in residential and parkland soils and requires investigation of potential metal accumulation in these soils.

This study was carried out to determine composition of soil and evaluate the background level of trace elements [including heavy metals] in soils of the play structures of elementary schools in Brandon. Also the range of heavy metal concentration and distribution was investigated. The acquired information was used to assess possible soil contamination and identify source of contamination. Such evaluation is important to identify which playgrounds [if any] have contaminated soil which may need remediation.

\section{METHODOLOGY}

Brandon, the second-largest city in the province of Manitoba, Canada, is located in the southwestern corner of the province near the Assiniboine River, approximately $214 \mathrm{~km}$ west of the provincial capital, Winnipeg. The playgrounds in the Brandon elementary schools show low variety of geological and lithological conditions. The area investigated is characterized by prairie setting with flat morphology and uniform pedolandscape related to the parent material and to the geomorphic surfaces the soils originated from. The soil parent materials in the area investigated are mainly glacial and alluvial deposits; shale bedrock is only exposed in Souris town $47 \mathrm{~km} \mathrm{SW}$ of Brandon. Farming is the main land utilization type in the area.

A total of 73 samples were collected from playgrounds [specifically soil in the play structure areas] of 16 elementary schools in Brandon (Figure 1) in sunny days of June-July 2015. The focus was on the play structure areas because most of students spend more time in these areas. The number of samples from each playground varies between 2 and 8 depending on availability of proper samples as well as size of the playgrounds. Samples were selected from surface $[0-10 \mathrm{~cm}]$ of soil in the playgrounds. Each main soil sample $[1-3 \mathrm{~kg}]$, consisted of 3-5 sub-samples, were randomly taken from the surroundings of each site, pooled and homogenized to form a representative sample. All samples were kept in sealed packages to avoid contamination and transported to the laboratory at Brandon University immediately. The samples were dried in room temperature to release any potential vapour and moisture. Then they were sieved and portion finer than 60 mesh in each sample [in solid form] was analysed by X-ray florescence [XRF]. The samples were analysed twice and the average values are used in this paper. In case the two assays were not similar, the third analysis was performed. The quality control was performed using eight standard samples. The concentrations and standard deviation for trace elements are shown in Table 1.

\section{RESULTS}

All studied samples mainly have high silica content reflecting their quartzrich sandy characteristic. Some carbonate accompanies sand in some school soil. This is reflected in the chemistry of those samples as high $\mathrm{Ca}$ and $\mathrm{Mg}$ [e.g. Waverly Park school]. Potassium, $\mathrm{Ca}$, and $\mathrm{Al}$ are mainly within feldspars and/or clay in the samples. Titanium is detected in some school soil; it mainly occurs as $\mathrm{TiO}_{2}$ in sands. Minor amount of phosphor reflects transported apatite $\left[\mathrm{Ca}_{5}\left(\mathrm{PO}_{4}\right)_{3}\right]$ grains in sand.

As trace and heavy metals can be toxic, their concentrations for each school (Table 1) are discussed in details below. Barium is a heavy trace metal that was detected in all studied samples and is discussed as well.

\section{J.R. Reid school}

\section{4 samples from the volleyball field of this school show the following.}

-7-14 ppm As: The Canadian soil quality guidelines suggest $12 \mathrm{ppm}$ as acceptable As level in parkland and residential fields (18). It appears that only one sample from this school has higher arsenic [14 ppm] however considering standard deviation [STD] of the used analytical method (3 ppm, Table 1), it appears that As in this sample is close to the guideline level.

-399-545 ppm Ba: Two samples have higher Ba [508 and 545 ppm] than the guideline suggestion [500 ppm]. Considering high STD [34 ppm], it seems that $\mathrm{Ba}$ in these 2 samples is close to the guideline level.

- Only one sample showed $37 \mathrm{ppm} \mathrm{Cu}$ which is below the guideline level [63 ppm]. In the rest of samples, Cu was below detection limit.

-14-16 ppm Pb: All samples have less Pb than the Canadian soil quality guideline [140 ppm].

- Mn was not detected.

- 41-56 ppm Zn: Similar to $\mathrm{Pb}$, all analysed samples have less zinc than the Canadian soil quality guideline [200 ppm].

\section{Kirkcaldy Heights school}

2 samples from the small playground and 2 samples from the larger playground of this school show the following.

-6-8 ppm As: All samples have less arsenic than the Canadian soil quality guideline [12 ppm].

-277-512 ppm Ba: Only one sample has higher Ba [512 ppm] than the guideline level $[500 \mathrm{ppm}$ ]. High STD [34 ppm] suggests that $\mathrm{Ba}$ in this sample is very close to the guideline level.

-31-280 ppm Cu: Copper was not detected in one sample. Two samples contain 70 and $280 \mathrm{ppm} \mathrm{Cu}$ which are above acceptable level [63 ppm]. The sample with $70 \mathrm{ppm} \mathrm{Cu}$ probably has about the guideline level [considering $\mathrm{Cu}$ STD of $18 \mathrm{ppm}$ ( (Table 1). However, sample with $280 \mathrm{ppm} \mathrm{Cu}$ has much more $\mathrm{Cu}$ than the acceptable level. This sample is from the large playground.

-8-23 ppm Pb: All samples have less arsenic than the Canadian soil quality guideline [140 ppm].

-1267-3301 ppm Mn: Manganese was not detected in one sample. Acceptable level of $\mathrm{Mn}$ in residential and parklands of Canada is not known.

-60-133 ppm Zn: Similar to $\mathrm{Pb}$, all analysed samples have less zinc than the Canadian soil quality guideline [200 ppm].

\section{Meadows school}

Five samples from sandbox and small playground of this school show the following results.

-6-12 ppm As: All samples have less arsenic than, or close to, the Canadian soil quality guideline [12 ppm]. 
TABLE 1

Trace element concentration (in ppm) in soil samples of playgrounds in the elementary schools of Brandon. Major elements (in \%) are also shown. $\mathrm{Ni}, \mathrm{Se}, \mathrm{U}, \mathrm{V}, \mathrm{Cd}$, and $\mathrm{Cr}$ were below detection limit and are not shown. $\mathrm{ND}=$ not detected. Acceptable levels (in ppm) are from CCME (18)

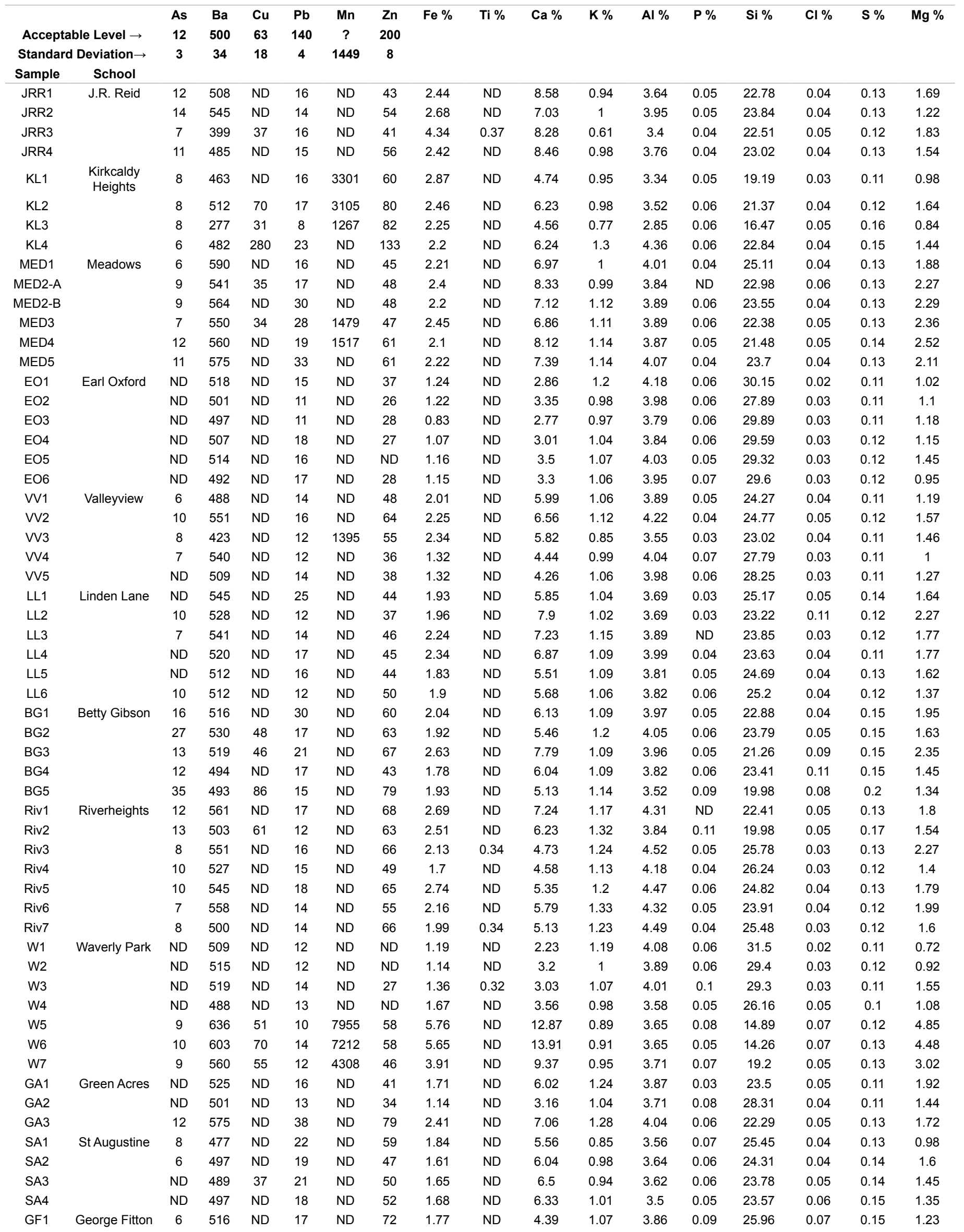




\begin{tabular}{|c|c|c|c|c|c|c|c|c|c|c|c|c|c|c|c|c|c|}
\hline GF2 & & 7 & 489 & ND & 12 & ND & 59 & 1.83 & ND & 5.28 & 1.06 & 3.82 & 0.09 & 25.13 & 0.07 & 0.14 & 1.63 \\
\hline GF3 & & 8 & 497 & 51 & 17 & ND & 153 & 2.41 & 0.38 & 5.16 & 1.18 & 4.25 & 0.08 & 23.34 & 0.05 & 0.16 & 1.49 \\
\hline $\mathrm{EH} 1$ & Ecol Harrison & 8 & 517 & ND & 12 & ND & 42 & 1.98 & ND & 6.59 & 0.94 & 4.06 & ND & 23.65 & 0.05 & 0.13 & 1.66 \\
\hline $\mathrm{EH} 2$ & & 10 & 528 & ND & 11 & ND & 34 & 2.1 & ND & 5.92 & 0.94 & 4.18 & 0.04 & 25.41 & 0.04 & 0.14 & 1.7 \\
\hline $\operatorname{Re} 1$ & Riverview & 11 & 481 & ND & 12 & ND & 42 & 1.74 & ND & 5.15 & 1.13 & 3.71 & 0.03 & 24.81 & 0.04 & 0.11 & 0.68 \\
\hline $\mathrm{Re} 2$ & & 6 & 490 & ND & 11 & ND & 45 & 1.34 & ND & 4.62 & 0.98 & 3.71 & 0.04 & 25.94 & 0.03 & 0.11 & 1.3 \\
\hline Re3 & & 7 & 511 & ND & 14 & ND & 45 & 1.98 & ND & 5.01 & 1 & 3.98 & 0.04 & 26.59 & 0.03 & 0.11 & 1.8 \\
\hline Re4 & & 7 & 481 & ND & 9 & ND & 41 & 2.32 & ND & 6.37 & 0.86 & 3.62 & 0.05 & 25.91 & 0.04 & 0.11 & 1.17 \\
\hline NE1 & New Era & 12 & 466 & 30 & 25 & 1574 & 93 & 2.63 & ND & 7.32 & 0.87 & 3.55 & ND & 23.45 & 0.05 & 0.17 & 1.34 \\
\hline NE2 & & 12 & 456 & 30 & 12 & 2116 & 83 & 2.7 & ND & 7.78 & 0.83 & 3.69 & ND & 25.27 & 0.06 & 0.12 & 1.62 \\
\hline NE2 & & ND & 335 & 42 & 15 & 2015 & 78 & 2.49 & ND & 6.47 & 0.78 & 3.19 & ND & 21.09 & 0.04 & 0.11 & 1.49 \\
\hline NE4 & & 13 & 465 & 33 & 15 & 5146 & 75 & 2.8 & ND & 10.2 & 0.8 & 3.39 & ND & 18.75 & 0.06 & 0.12 & 2.45 \\
\hline NE5 & & 18 & 459 & 45 & 14 & 3915 & 68 & 2.74 & ND & 9.25 & 0.76 & 3.25 & ND & 21 & 0.06 & 0.12 & 2.31 \\
\hline KG1 & King George & 12 & 541 & 77 & 22 & 3572 & 81 & 3.79 & ND & 7.17 & 1.17 & 4.41 & 0.05 & 22.55 & 0.04 & 0.13 & 2.18 \\
\hline KG2 & & 7 & 474 & 111 & 31 & 3877 & 193 & 3.65 & ND & 6.6 & 1.01 & 4.01 & 0.08 & 21.96 & 0.05 & 0.18 & 2.17 \\
\hline KG3 & & 12 & 510 & 43 & 12 & 3894 & 69 & 3.68 & ND & 7.26 & 1.02 & 3.93 & 0.04 & 20.61 & 0.04 & 0.11 & 1.1 \\
\hline KG4 & & 8 & 525 & 52 & 16 & 4351 & 85 & 3.9 & ND & 8.7 & 0.99 & 4.07 & 0.06 & 21.72 & 0.05 & 0.13 & 2.09 \\
\hline
\end{tabular}

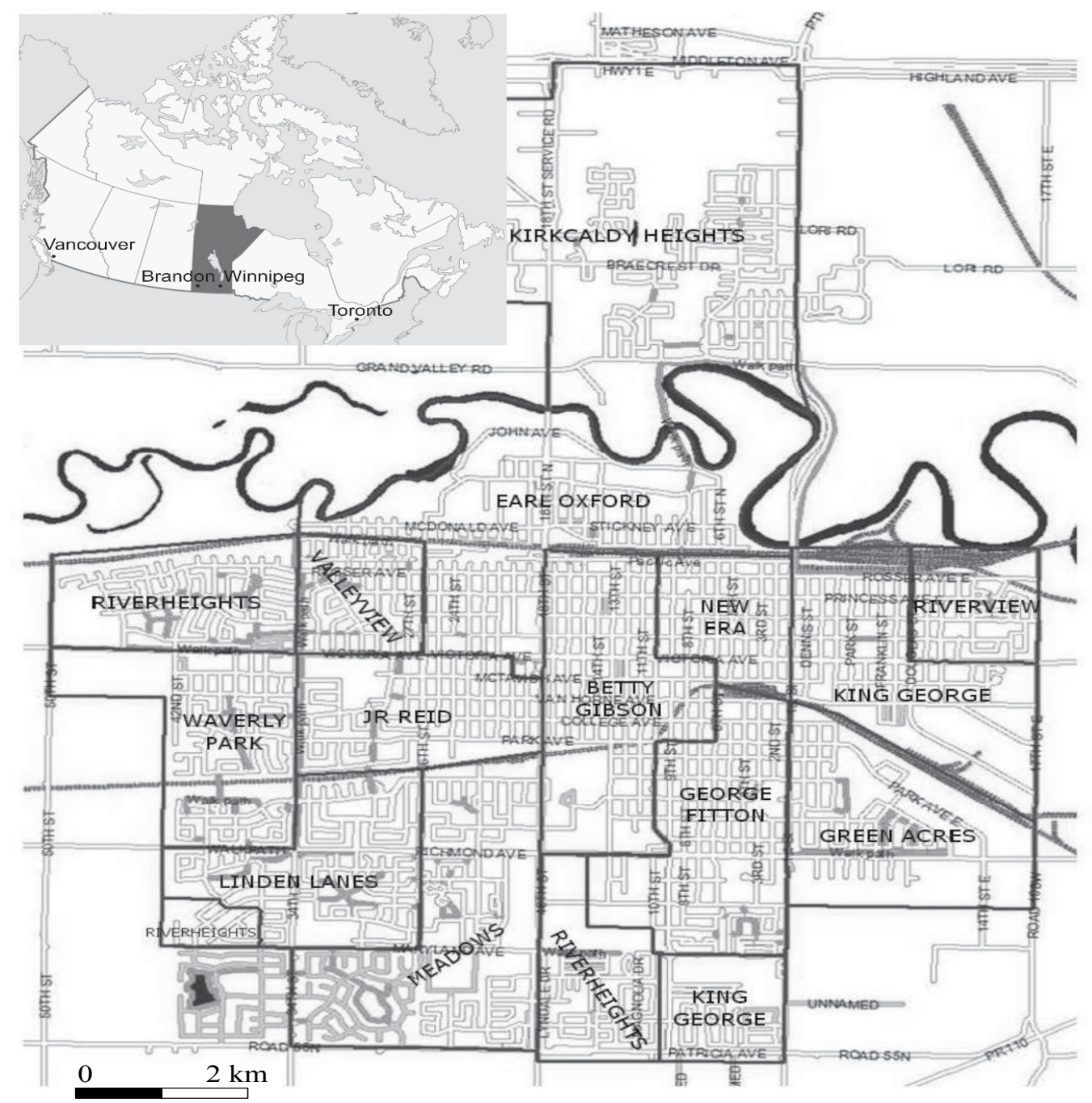

Figure 1) Elementary schools of Brandon, Canada

-541-590 ppm Ba: All analysed samples contain higher Ba than the guideline suggestion [500 ppm]. However high STD [34 ppm] suggests that $\mathrm{Ba}$ in these samples is close or higher than the guideline level.

-34-35 ppm Cu: Copper was detected in two samples. Both samples contain less $\mathrm{Cu}$ than the guideline level [63 ppm].

-16-33 ppm $\mathrm{Pb}$ : All samples have less $\mathrm{Pb}$ than the Canadian soil quality guideline [140 ppm].

-1479-1517 ppm Mn: It was detected in two samples.

-45-61 ppm Zn: All analysed samples have less Zn than the Canadian soil quality guideline [200 ppm].

\section{Earl Oxford school}

Six samples from the sandy playground of this school show the following results.

- Arsenic was not detected.

- 492-518 ppm Ba: Considering Ba STD [34 ppm], all these samples have close to the Canadian soil quality guideline $[500 \mathrm{ppm}]$.

- $\mathrm{Cu}$ was not detected.

-11-18 ppm Pb: All samples have less $\mathrm{Pb}$ than the Canadian soil quality guideline [140 ppm]. 
- Mn was not detected.

-26-37 ppm Zn: All analysed samples have less Zn than the Canadian soil quality guideline [200 ppm]. Zn was not detected in one sample.

\section{Valley-View school}

Five samples from the gravel \pm sand playground of this school show the following results.

-6-10 ppm As: All samples have less arsenic than the Canadian soil quality guideline [12 ppm]. Arsenic was less than detection limit in one sample.

-423-551 ppm Ba: Considering Ba STD [34 ppm], some of these samples have close to the Canadian soil quality guideline [500 ppm].

- Cu was not detected.

-12-16 ppm $\mathrm{Pb}$ : All samples have less $\mathrm{Pb}$ than the Canadian soil quality guideline [140 ppm].

-Mn was detected only in one sample [1395 ppm].

-36-64 ppm Zn: All analysed samples have less Zn than the Canadian soil quality guidelines [200 ppm].

\section{Linden Lane school}

Six samples from the sand \pm gravel playground of this school show the following results.

- 7-10 ppm As: Arsenic was detected only in 3 samples which have less As than the Canadian soil quality guideline [12 ppm].

- 512-545 ppm Ba: Considering Ba STD [34 ppm], all of these samples have Ba probably close to the Canadian soil quality guideline [500 ppm].

- Cu was not detected.

-12-25 ppm Pb: All samples have less $\mathrm{Pb}$ than the Canadian soil quality guideline [140 ppm].

- Mn was not detected.

-37-50 ppm Zn: All analysed samples have less Zn than the Canadian soil quality guidelines [200 ppm]

\section{Betty Gibson school}

Five samples were collected from the sand \pm gravel playground.

-12-35 ppm As: All analysed samples have arsenic close to, or higher than, the Canadian soil quality guideline [12 ppm].

-493-530 ppm Ba: Considering Ba STD [34 ppm], all of the analyzd samples have $\mathrm{Ba}$ close to the Canadian soil quality guideline [500 ppm].

- 46-86 ppm Cu: Copper was detected in 3 samples. One sample contains 86 ppm Cu which could be close to the Canadian soil quality guidelines [63 ppm] considering Cu STD [18 ppm]

-15-30 ppm $\mathrm{Pb}$ : All samples have less $\mathrm{Pb}$ than the Canadian soil quality guideline [140 ppm].

- Mn was not detected.

-43-79 ppm Zn: All analysed samples have less Zn than the Canadian soil quality guideline [200 ppm].

\section{Riverheights school}

Seven samples were collected from the sandy parts of the main play structure, volleyball field and swinging area.

- 7-13 ppm As: Considering As STD [3 ppm], all analysed samples have arsenic close to, or lower than, the Canadian soil quality guideline [12 ppm].

-500-561 ppm Ba: Considering Ba STD [34 ppm], all samples have Ba probably close to, or slightly higher than, the Canadian soil quality guideline [500 ppm].

- $\mathrm{Cu}$ was detected only in one sample. This sample has lower Cu [61 ppm] than the Canadian soil quality guideline [63 ppm].

-12-18 ppm $\mathrm{Pb}$ : All samples have less $\mathrm{Pb}$ than the Canadian soil quality guideline [140 ppm].

- Mn was not detected.
- 49-68 ppm Zn: All analysed samples have less Zn than the Canadian soil quality guideline [200 ppm].

\section{Waverly Park school}

Seven samples were collected from the large gravel \pm sand play structure.

-9-10 ppm As: Arsenic was detected only in 3 samples which contain As less than the Canadian soil quality guideline [12 ppm].

-488-636 ppm Ba: Considering Ba STD [34 ppm], these samples have Ba probably close to, or higher than, the Canadian soil quality guidelines [500 ppm].

- 51-70 ppm Cu: It was detected in 3 samples which contain less than, or close to, the Canadian soil quality guideline [63 ppm] considering CU STD [18 ppm].

-10-14 ppm Pb: All samples have less Pb than the Canadian soil quality guideline $[140 \mathrm{ppm}]$.

-4308-7955 ppm Mn was detected in 3 samples.

-27-58 ppm Zn: Zinc was detected in 4 samples which contain $\mathrm{Zn}$ less than the Canadian soil quality guideline [200 ppm].

\section{Green Acres school}

The main play structure had only gravel and was not sampled. Three samples were collected from gravel \pm sand ground in the swinging area.

- Arsenic was detected only in one sample [12 ppm] which contains As close to the Canadian soil quality guideline [12 ppm].

- 501-575 ppm Ba: Considering Ba STD [34 ppm], all samples have Ba probably close to, or slightly higher than, the Canadian soil quality guideline [500 ppm]

- Cu was not detected.

-13-38 ppm $\mathrm{Pb}$ : All samples have less $\mathrm{Pb}$ than the Canadian soil quality guideline $[140 \mathrm{ppm}]$.

- Mn was not detected.

-34-79 ppm Zn: Zinc was detected in all 3 samples which contain Zn less than the Canadian soil quality guideline [200 ppm].

\section{St Augustine school}

Four samples were collected from the sand \pm gravel playground.

-6-8 ppm As: Arsenic was detected only in 2 samples which contain As less than the Canadian soil quality guideline [12 ppm].

- 477-497 ppm Ba: All 4 samples contain Ba less than the Canadian soil quality guideline [500 ppm].

- $\mathrm{Cu}[37 \mathrm{ppm}]$ was detected in one sample which is less than the Canadian soil quality guideline [63 ppm].

-18-22 ppm $\mathrm{Pb}$ : All samples have less $\mathrm{Pb}$ than the Canadian soil quality guideline [140 ppm].

- Mn was not detected.

- 47-59 ppm Zn: It was detected in all 4 samples which contain $\mathrm{Zn}$ less than the Canadian soil quality guideline [200 ppm]

\section{George Fitton school}

The main play structure area had gravel and was not sampled. Three samples were collected from the sandy swinging area.

-6-8 ppm As: All samples contain arsenic less than the Canadian soil quality guideline [12 ppm].

-489-516 ppm Ba: All samples contain Ba less than, or close to, the Canadian soil quality guideline [500 ppm].

- $\mathrm{Cu}[51 \mathrm{ppm}]$ was detected in one sample which contains less $\mathrm{Cu}$ than the Canadian soil quality guideline [63 ppm].

-12-17 ppm $\mathrm{Pb}$ : All samples have less $\mathrm{Pb}$ than the Canadian soil quality guideline [140 ppm].

- Mn was not detected.

- 59-153 ppm Zn: It was detected in all 4 samples which contain Zn less than the Canadian soil quality guideline [200 ppm]. 


\section{Ecol Harrison school}

Two samples were collected from the sandy volleyball field.

-8-10 ppm As: Both samples contain arsenic less than the Canadian soil quality guideline [12 ppm].

-517-528 ppm Ba: Both samples contain Ba close to the Canadian soil quality guidelines [500 ppm], considering Ba STD [34 ppm].

- Cu was not detected.

-11-12 ppm Pb: Both samples have less $\mathrm{Pb}$ than the Canadian soil quality guideline [140 ppm].

- Mn was not detected.

-34-42 ppm Zn: Both samples contain Zn less than the Canadian soil quality guidelines [200 ppm].

\section{Riverview school}

The main play structure area had gravel and was not sampled. Four samples were collected from the sandy swinging area.

-6-11 ppm As: All samples contain arsenic less than the Canadian soil quality guideline [12 ppm].

-481-511 ppm Ba: All samples contain Ba less than, or close to, the Canadian soil quality guideline [500 ppm].

- Cu was not detected.

-9-14 ppm Pb: All samples have less $\mathrm{Pb}$ than the Canadian soil quality guideline [140 ppm].

- Mn was not detected.

- 41-45 ppm Zn: It was detected in all 4 samples which contain $\mathrm{Zn}$ less than the Canadian soil quality guideline [200 ppm].

\section{New Era school}

Five samples were collected from the main gravel \pm sand playground.

-12-18 ppm As: Four samples contain arsenic close to, or slightly higher than, the Canadian soil quality guideline [12 ppm] considering As STD [3 ppm]. Arsenic was not detected in one sample.

-335-466 ppm Ba: All samples contain Ba less than the Canadian soil quality guideline [500 ppm].

-30-45 ppm Cu: Copper was detected in all 5 samples which contain less $\mathrm{Cu}$ than the Canadian soil quality guideline [63 ppm].

-12-25 ppm Pb: All samples have less $\mathrm{Pb}$ than the Canadian soil quality guideline [140 ppm].

-1574-5146 ppm Mn was detected in all samples.

-68-93 ppm Zn: Zinc was detected in all 4 samples which contain Zn less than the Canadian soil quality guideline [200 ppm].

\section{King George school}

Four samples were collected from below the main gravel playground.

-7-12 ppm As: All 4 samples contain arsenic close to, or lower than, the Canadian soil quality guideline [12 ppm].

-474-541 ppm Ba: All samples contain Ba close to the Canadian soil quality guideline [500 ppm], considering Ba STD [34 ppm].

-43-111 ppm Cu: It was detected in all 4 samples. Only one sample [with 111 ppm $\mathrm{Cu}$ ] has higher $\mathrm{Cu}$ than the Canadian soil quality guideline [63 ppm].

-12-31 ppm Pb: All samples have less $\mathrm{Pb}$ than the Canadian soil quality guideline [140 ppm].

-3572-4351 ppm Mn was detected in all samples.

-69-193 ppm Zn: It was detected in all 4 samples which contain Zn less than the Canadian soil quality guideline [200 ppm].

\section{DISCUSSION}

Heavy metal contamination in various types of soil usages have been studied worldwide $(4,5,13,15,17)$. Various countries have developed guidelines on the acceptable concentration of some elements in soil in order to protect the ecological receptors in the environment and / or human health for various land applications. The maximum acceptable level is defined as the highest concentration at which diverse health effects are not seen in the exposed receptor. Level of heavy metals and other elements in any receptor depends on type of land use and method of exposure including inhalation, ingestion, dermal contact, or transfer via the placenta. For example, direct soil contact is the primary exposure pathway for residential / parkland, commercial, and industrial land uses; soil and food ingestion are the major exposure pathway in agricultural land use. The health effects of higher than maximum acceptable levels of these elements range from minor allergies to death. For example, an overt sign of lead intoxication is its effect on central nervous system (19).

Weathering of rocks [geogenic] and anthropogenic sources are the two main pathways of metal input to soils. Anthropogenic sources of metal contamination include metalliferous mining and smelting, industry, atmospheric deposition, agriculture, and waste disposal. Some heavy metals [e.g., $\mathrm{Cr}, \mathrm{Ni}, \mathrm{Cu}$, and partially $\mathrm{Zn}$ and $\mathrm{Pb}$ ] may originate from a natural source [i.e., geologic source such as the parent rock]. In agricultural ecosystems, with intense animal farming and other agricultural practices, heavy metal contamination [e.g., As, Cd, and $\mathrm{Zn}$ ] can occur due to the application of commercial fertilizers, sewage sludge and pesticides which usually contain a wide variety of heavy metals as impurities (20). Other causes of pollution are atmospheric deposition due to proximity to industrial plants $(21,22)$, combustion of fossil fuels $(23,24)$ industry and traffic sources [e.g., $\mathrm{Hg}$ and $\mathrm{Pb}$, and other human activities (25). In addition, lead concentration of soil can contribute to indoor dust lead contamination (26).

The occasional or continuous addition of sediments to soil profiles, as well as organic matter accumulation and humification, make up the soil-forming processes of the greatest importance to the distribution of pseudo-total heavy metals. The background levels of elements in a particular soil depends strongly on the mineralogical composition of the parent material in the soil and the weathering processes that led to the formation of the soil $(15,27)$. The grain size (28), clay and organic matter content $(29,30)$ are also important. Heavy metals are mobilized in the biosphere due to human activity and this has significantly increased the circulation of toxic metals throughout the environment. As a result, from functional point of view, each site with soil component should have specific chemical composition to be used as agricultural and residential/parkland sites. Sensitivity to contamination in such sites is high due to ecological and human health issues.

Amongst the studied heavy metals, only $\mathrm{As}$, Ba and $\mathrm{Cu}$ in some schools show higher than or close to the values suggested by the Canadian soil quality guidelines. Overall, samples from the Betty Gibson school have higher As than those from other schools. One sample from this school has the highest amount of As [35 ppm] amongst the studied samples. This sample also has the highest $\mathrm{S}$ concentration suggesting presence of arsenic as a natural sulfarsenide. This is supported by weak positive correlation between As and $\mathrm{S}$ when all samples are used in the diagram (Figure 2) which suggests that arsenic occurs mainly as sulfarsenide such as arsenopyrite [FeAsS] in soil of playgrounds in the elementary schools of Brandon. However, Fe-S diagram (Figure 3) shows that two samples with the highest As concentrations [27 and $35 \mathrm{ppm}$ ] from the Betty Gibson school do not plot on the arsenopyrite [FeAsS] trend. This may indicate that As occurs as different type of sulfarsenide in these two samples.

There is a wide range of acceptable As guidelines worldwide. For instance, the As guideline varies widely in the United States from $0.04 \mathrm{ppm}$ to 40 ppm depending on the naturally occurring background levels of As. The international guidelines have diverse foundations with widely varying As concentrations which are consistently higher than the US numbers. For example, the As guidelines for UK, Netherlands, Australia and Japan are respectively $32,76,100$, and $150 \mathrm{ppm}$ (31). The $12 \mathrm{ppm}$ Canadian guideline for As is very conservative.

Although arsenic is a toxic element, its toxicity from a sulfarsenide source such as arsenopyrite depends on its solubility which is controlled by $\mathrm{pH}$ $\mathrm{Fe}$, and dissolved oxygen content of water (32). In groundwater, arsenic can be present as arsenide under reducing conditions and as arsenate under oxidizing conditions. Ferric hydroxide $\mathrm{Fe}^{3+}[\mathrm{OH}]$ bonds strongly with the soluble arsenate under oxidizing condition and removes As from the solution.

Barium concentrations are lower than the Canadian soil quality guideline in samples from most schools. It is higher or close to the guideline only in some samples of Meadows and Waverly Park schools. Barium occurs mainly as barite $\left[\mathrm{BaSO}_{4}\right]$ and witherite $\left[\mathrm{BaCO}_{3}\right]$ in natural samples $(33,34)$. If barite 


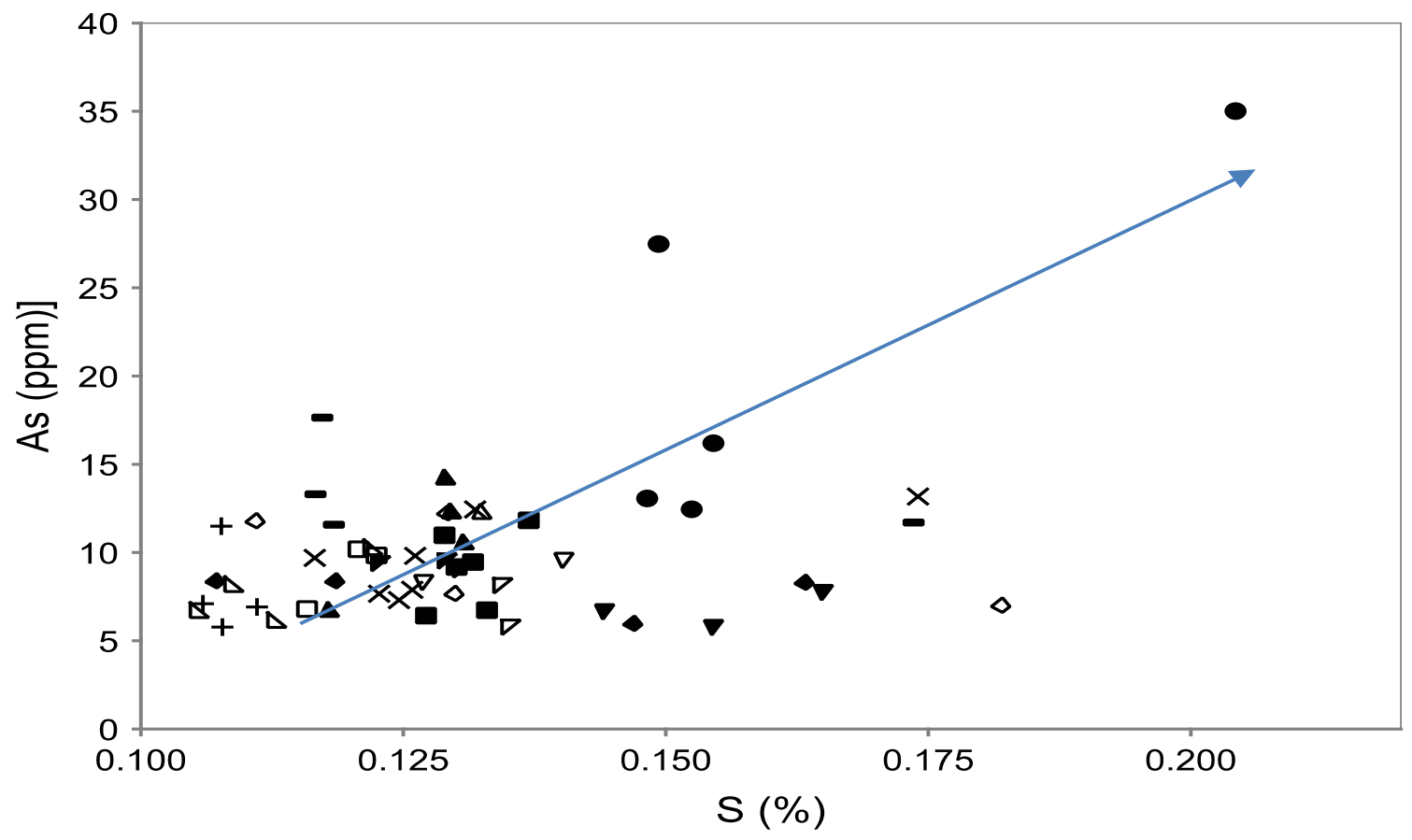

Figure 2) As-S diagram showing weak positive correlation

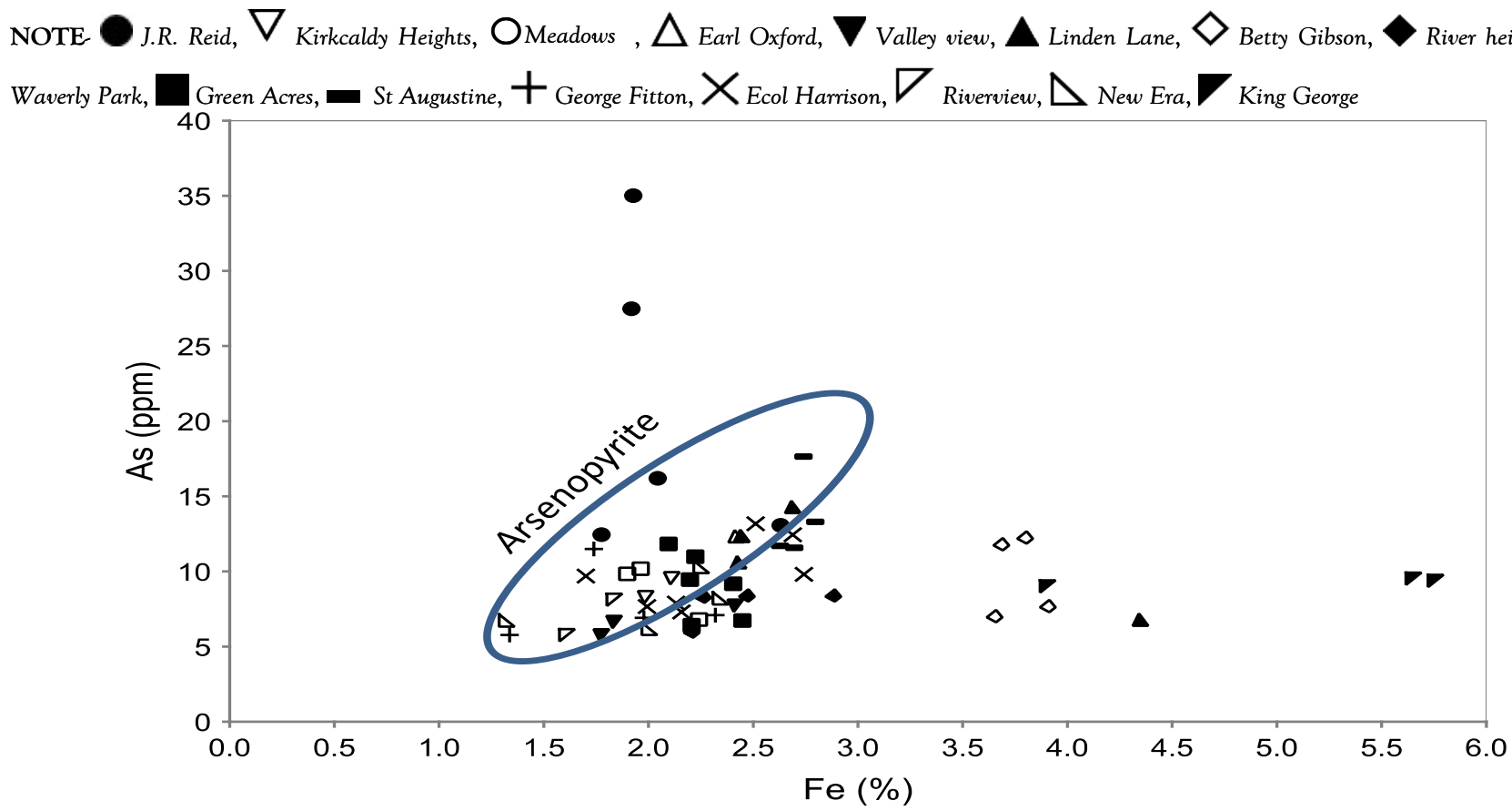

Figure 3) Fe-S diagram showing arsenopyrite trend

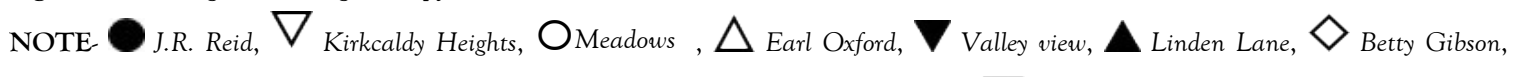

Waverly Park, Green Acres, St Augustine, $十$ George Fitton, $\chi_{\text {Ecol Harrison, }} \nabla_{\text {Riverview, }} \Delta$ New Era, $\boldsymbol{V}$ King George

is the main Ba mineral, a positive correlation is expected between $\mathrm{Ba}$ and $\mathrm{S}$.

In the studied samples, such positive correlation is observed in samples with low $S$ content (Figure 4), however the correlation of Ba with $S$ is obscured in samples with high $\mathrm{S}$ content possibly due to the presence of $\mathrm{S}$ in other $\mathrm{Ba}$ free S-bearing minerals such as $\mathrm{Cu}$ and $\mathrm{Zn}$ sulfides. As a result, samples with high $\mathrm{S}$ do not show positive correlation with Ba. Although barium is a heavy metal, its health effects strongly depend on the solubility of its compounds. Water-soluble compounds of Ba are often highly toxic whereas barium sulfate has low solubility and is readily removed from the body (35); that is why it is frequently utilized as a benign, radiopaque aid to X-ray diagnosis. This indicates that barite $\left[\mathrm{BaSO}_{4}\right]$ is an insoluble compound which is generally nontoxic to humans (36).

Copper concentrations are lower than the guideline in the playgrounds of most schools and only 4 samples from 3 schools contain higher or close to the Canadian soil quality guideline: Kirkcaldy [one sample], Betty Gibson [possibly one sample] and King George [possibly 2 samples] schools. Sulfur shows positive correlation with $\mathrm{Cu}$ and $\mathrm{Zn}$ (Figure 5) suggesting that $\mathrm{Cu}$ and $\mathrm{Zn}$ occur as their predominate sulfide phases; $\mathrm{Cu}$ as chalcopyrite $\left[\mathrm{CuFeS}_{2}\right]$, bornite $\left[\mathrm{Cu}_{5} \mathrm{FeS}_{4}\right]$, covellite $[\mathrm{CuS}]$, or chalcocite $\left[\mathrm{Cu}_{2} \mathrm{~S}\right]$, and $\mathrm{Zn}$ as sphalerite [ZnS]. The highest $\mathrm{Cu}$ [280 ppm from Kirkcaldy School] does not correspond with the highest $\mathrm{S}$ concentration which possibly suggests that $\mathrm{Cu}$ in this sample is present in non-sulfide form as well.

Lead is lower than the Canadian soil quality guideline in all samples from the studied schools. The positive correlation of $\mathrm{Pb}$ with $\mathrm{S}$ is obscured (Figure 6) likely due to presence of $\mathrm{S}$ in other S-bearing minerals such as $\mathrm{Cu}$ and $\mathrm{Zn}$ sulfides. 


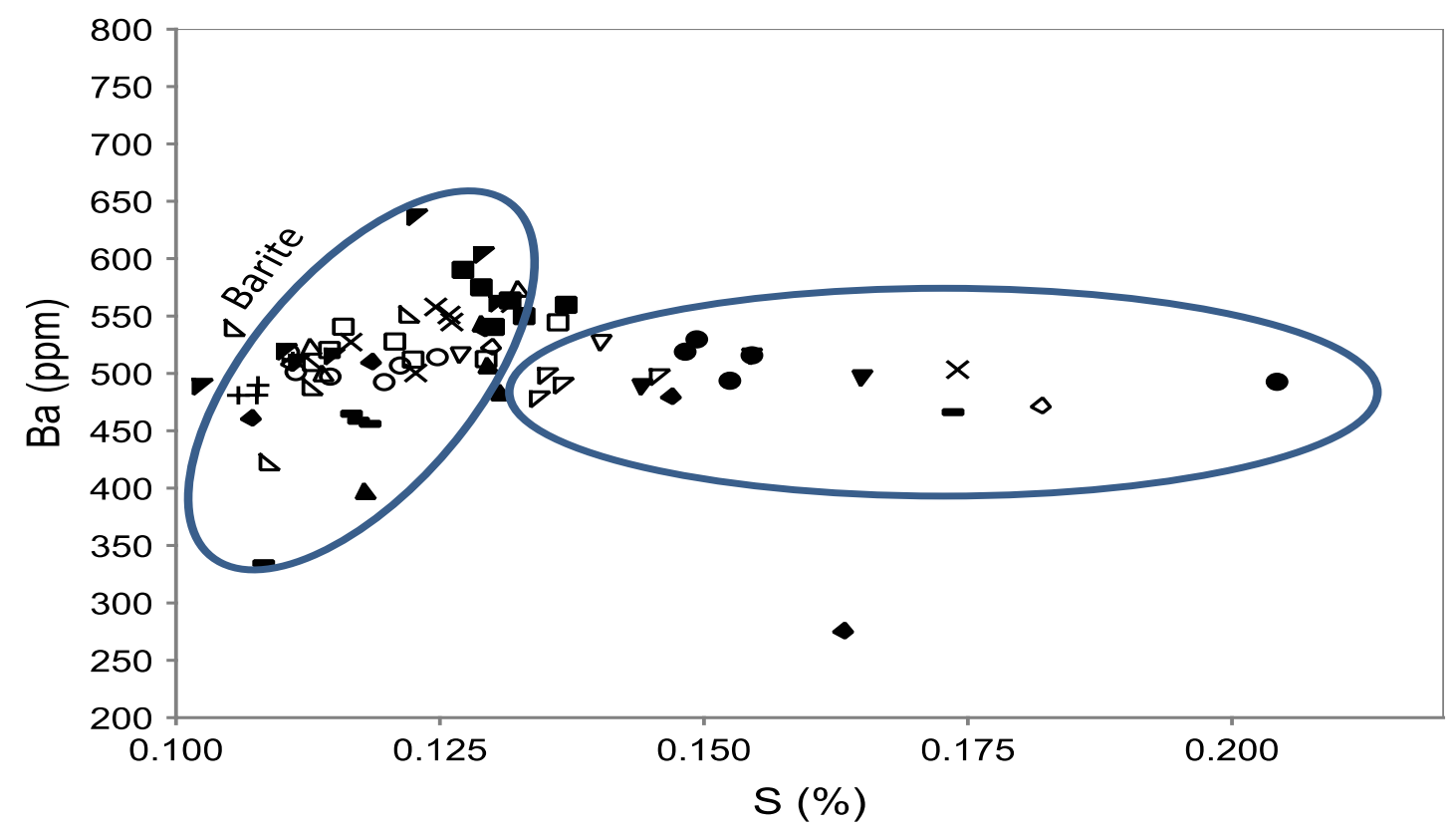

Figure 4) Ba-S diagram showing presence of barite and sulfides in the studied samples

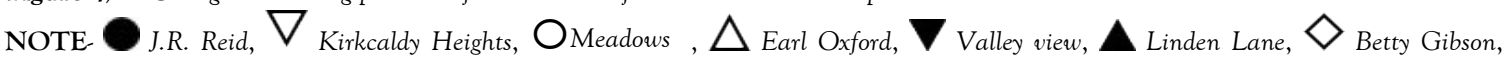
River heights, Waverly Park,
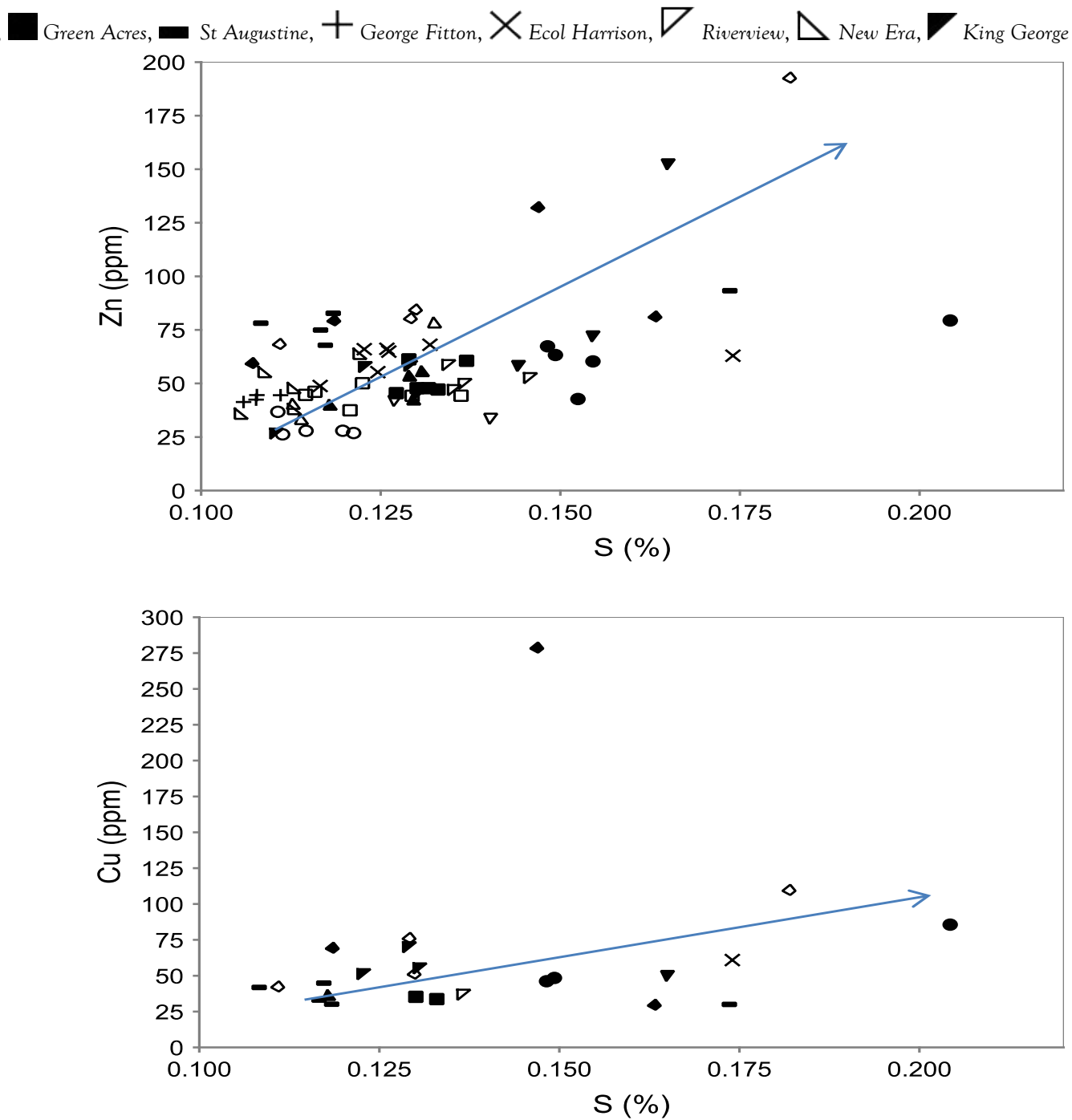

Figure 5) $\mathrm{Zn}$-S and $\mathrm{Cu}$-S diagrams showing positive correlation between heavy metals and $\mathrm{S}$

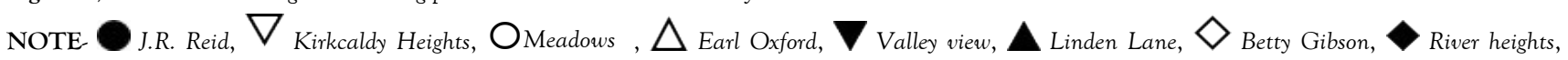
Waverly Park, Green Acres, $\square$ St Augustine, $十$ George Fitton, $\chi_{\text {Ecol Harrison, }} \nabla_{\text {Riverview, }} \triangle$ New Era, $\boldsymbol{V}$ King George 


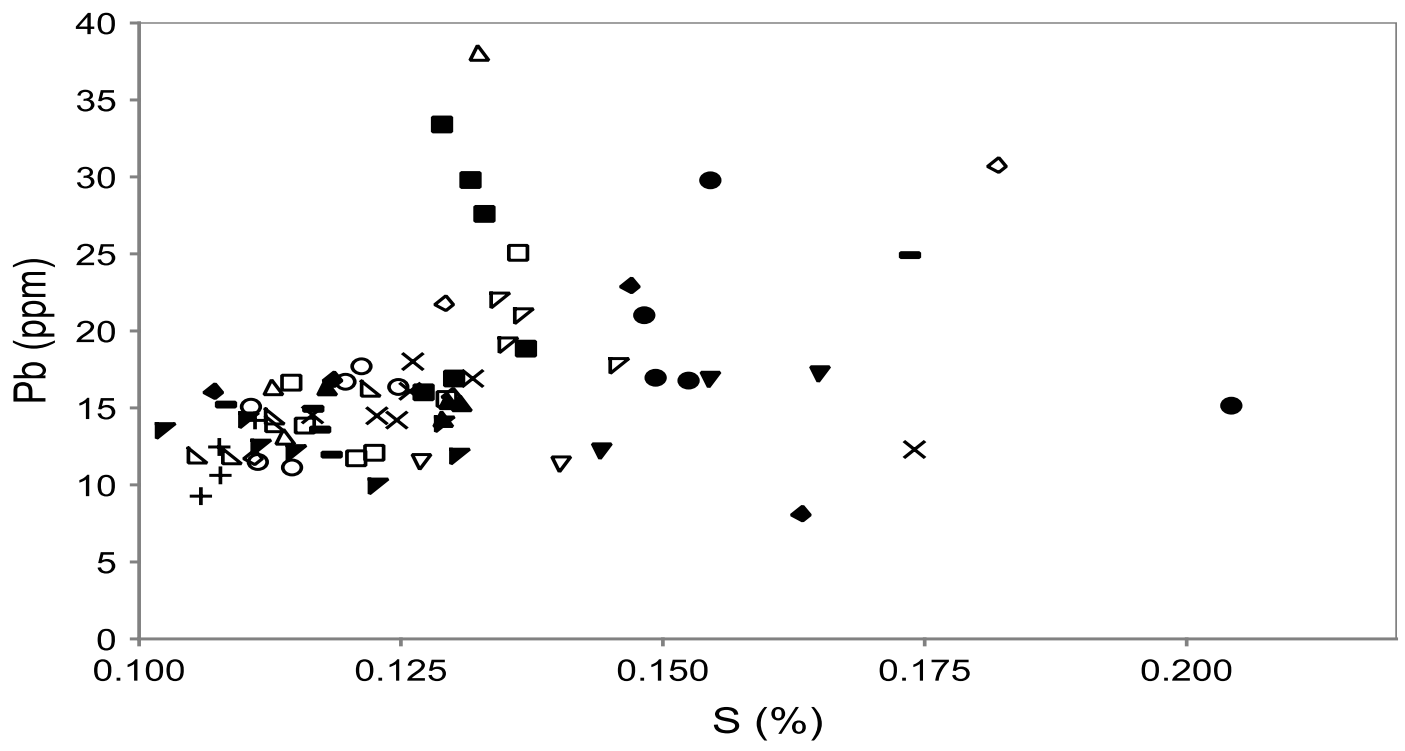

Figure 6) Pb-S diagram showing unclear correlation

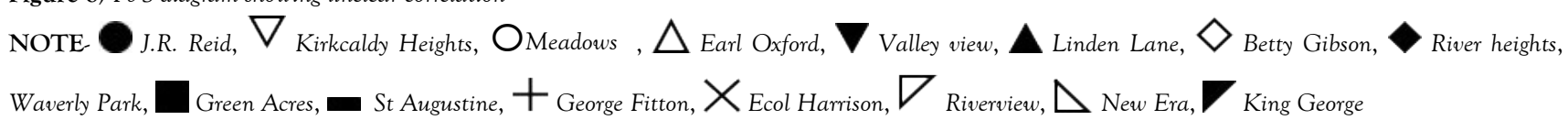

CONCLUSION

European cities. Journal of Environmental Monitoring 2006;8:1158-65.

22 elements including 6 common heavy trace elements were studied in soil samples from the play structure areas of the elementary schools of Brandon. Only As, Ba, and Cu concentrations in some samples from a few schools are close to, or higher than, the Canadian soil quality guideline. Barium occurs as insoluble barium sulfate [barite] in the studied samples. This mineral is generally considered nontoxic to humans. As and $\mathrm{Cu}$ distribution is mainly geogenic and they occur mostly as their natural minerals such as sulfides and sulfarsenides. The elemental relationships in the studied samples show that the data sets were predominantly influenced by natural geologic element dispersion and accumulation processes. Anthropogenic sources generally enrich individual [or small number of] elements and, as a result, distributions are disturbed and skewed towards higher values in natural systems. Lower values are commonly free from anthropogenic influences.

\section{ACKNOWLEDGMENT}

The funding for this project was provided by the BUREC grant from Brandon University and contribution from the Brandon School Division. Dr. Michaels from Brandon School Division and BUREC committee members are thanked for their support. The manuscript benefited from comments by anonymous referees.

\section{REFERENCES}

1. Horn A. High toxin levels in Townsville playgrounds alarms researchers. ABC 2014

2. Elom NI, Entwistle JA, Dean JR. How safe is the playground? An environmental health risk assessment of $\mathrm{As}$ and $\mathrm{Pb}$ levels in school playing fields in NE England. Environmental Chemistry Letters 2013;11:343-51.

3. Huang SS, Liao QL, Hua M, et al. Survey of heavy metal pollution and assessment of agricultural soil in Yangzhong district, Jiangsu Province, China. Chemosphere 2007;67:2148-55.

4. Cai L, Xu Z, Ren M, et al. Source identilcation of eight hazardous heavy metals in agricultural soils of Huizhou, Guangdong Province, China. Ecotoxicology \& Environmental Safety 2012;78:2-8.

5. Manta DS, Angelone M, Bellanca A, et al. Heavy metals in urban soils: A case study from the city of Palermo (Sicily), Italy. Science of The Total Environment 2002;300:229-243.

6. Lavado RS, Zubillaga MS, Alvarez R, et al. Baseline levels of potentially toxic elements in Pampas soils. Soil and Sediment Contamination: An International Journal 2004;13:329-39.

7. Madrid L, Diaz-Barrientos E, Ruiz-Cortés E, et al. Variability in concentrations of potentially toxic elements in urban parks from six
8. Clark HF, Hausladen DM, Brabander DJ. Urban gardens: Lead exposure, recontamination mechanisms, and implications for remediation design. Environmental Research 2008;107: 312-19.

9. Zheng YM, Chen TB, He JZ. Multivariate geostatistical analysis of heavy metals in topsoils from Beijing, China. Journal of Soils and Sediments 2008;8:51-8.

10. Szynkowska MI, Pawlaczyk A, Lesniewska E, et al. Toxic Metal Distribution in Rural and Urban Soil Samples Affected by Industry and Traffic. Polish Journal of Environmental Studies 2009;18:1141-50.

11. Wei BG, Yang LS. A review of heavy metal contaminations in urban soils, urban road dusts and agricultural soils from China. Microchemical Journal 2010; 94:99-107

12. Heidary-Monfared S. Community garden heavy metal study. Unpublished research report. Ecology Action Center 2011:47.

13. Jien SH, Tsai CC, Hseu ZY, et al. Baseline concentrations of toxic elements in metropolitan park soils of Taiwan. Terrestrial and Aquatic Environmental Toxicology 2015;5:1-7.

14. Quarshie E, Nyarko BJB, Serfor-Armah Y. Studies of the Levels of Some Toxic Elements in Soil and Tailings from Bibiani Mining Area of Ghana. Research Journal of Environmental and Earth Sciences 2011;3:512-20.

15. Roca N, Pazos MS, Bech J. Background levels of potentially toxic elements in soils: A case study in Catamarca (a semiarid region in Argentina). Catena 2012;92:55-66.

16. CCME - Canadian Council of Ministers of the Environment Summary of a protocol for the derivation of environmental and human health soil quality guidelines. CCME, Winnipeg. 2007.

17. Clark HF, Brabander DJ, Erdil RM. Sources, sinks, and exposure pathways of lead in urban garden soil. Journal of Environmental Quality 2006;35:2066-74.

18. CCME - Canadian Council of Ministers of the Environment. Canadian soil quality guidelines for the protection of environmental and human health: Summary tables. Updated September, 2007. In: Canadian environmental quality guidelines, 1999, Canadian Council of Ministers of the Environment, Winnipeg. 2007.

19. Environment Canada. Canadian soil quality guidelines for lead: Environmental. Supporting document-Final draft. Science Policy and Environmental Quality Branch, Guidelines Division, Ottawa. 1996.

20. Nicholson FA, Smith SR, Alloway BJ, et al. An inventory of heavy metal 
input to agricultural soil in England and Wales. Science of the Total Environment 2003;311:205-19.

21. Oliva SR, Espinosa AJF. Monitoring of heavy metals in topsoils, atmospheric particles and plant leaves to identify possible contamination sources. Microchemical Journal 2007;86:131-39.

22. Zhao YF, Shi XZ, Huang B, et al. Spatial distribution of heavy metals in agricultural soils of an industry-based peri-urban area in Wuxi, China. Pedosphere 2007;17:44-51.

23. Madrid L, Diaz-Barrientos E, Madrid F. Distribution of heavy metal contents of urban soils in parks of Seville. Chemospher 2002;49:1301-08.

24. Sabin LD, Lim JH, Stolzenbach KD, et al. Atmospheric dry deposition of trace metals in the coastal region of Los Angeles, California, USA. Environmental Toxicology and Chemistry 2006;25:2334-41.

25. Facchinelli A, Sacchi E, Mallen L. Multivariate statistical and GISbased approach to identify heavy metal sources in soils. Environmental Pollution 2001;114:313-24.

26. Rasmussen PE, Subramanian KS, Jessiman BJ. A multi-element profile of house dust in relation to exterior dust and soils in the city of Ottawa, Canada. The Science of The Total Environment 2001;267:125-40.

27. Klassen RA. Geological factors affecting the distribution of trace metals in glacial sediments of central Newfoundland. Environmental Geology 1998;33:154-69.

28. Salminen R, Tarvainen T. The problem of defining geochemical baselines. A case study of selected elements and geological materials in Finland. Journal of Geochemical Exploration 1997;60:91-8.

29. Tack FMG, Verloo MG, Vanmechelen L, et al. Baseline concentration levels of trace elements as a function of clay and organic carbon content in soils in Flanders (Belgium). The Science of the Total Environment 1997;201:113-23.

30. Mellum HK, Arnesen AKM, Singh BR. Extractability and plant uptake of heavy metals in alum shale soils. Communications in Soil Science and Plant Analysis 1998;29:1183-98.

31. Teaf CM, Covert DJ, Teaf PA, et al. Arsenic cleanup criteria for soils in the US and abroad: Comparing guidelines and understanding inconsistencies. Proceedings of the Annual International Conference on Soils, Sediments, Water and Energy 2010;15:94-102.

32. Cama J, Asta MP, Acero P. Dissolution kinetics of arsenopyrite and its implication on arsenic speciation in the environment. In Bundschuh (eds). Natural arsenic in groundwaters of Latin America. CRC Press 2009:273-280

33. Boffito C. Barium. In: Kirk-Othmer Encyclopedia of Chemical Technology. John Wiley and Sons, New York, Chichester, Brisbane, Toronto and Singapore 1991;3:902-8.

34. DiBello PM, Manganaro JL, Aguinaldo ER. Barium compounds. In: Kirk-Othmer Encyclopedia of Chemical Technology. 4th edition, vol. 3. John Wiley and Sons, New York, Chichester, Brisbane, Toronto and Singapore. 1991;3:909-31.

35. CCME - Canadian Council of Ministers of the Environment. Canadian soil quality guidelines for the protection of environmental and human health: Barium. In: Canadian environmental quality guidelines, Canadian Council of Ministers of the Environment, Winnipeg 2013.

36. ATSDR (Agency for Toxic Substances and Disease Registry) Toxicological profile for Barium.: U.S. Department of Health and Human Services, Public Health Service, Atlanta, GA. 2007. 